\section{A Critical Discussion of Sartre on Love}

ABSTRACT: Pessimism about the stability of intra-personal relationships runs deeply in the philosophy of Jean-Paul Sartre. I begin by examining how this pessimism arises from Sartre's ontology, particularly considering the attitude of love towards the Other. then suggest that there may be space within Sartre's philosophy for a defense of love as a positive relation to the Other which need not be destined to cycle into attitudes toward the Other such as hate or masochism.

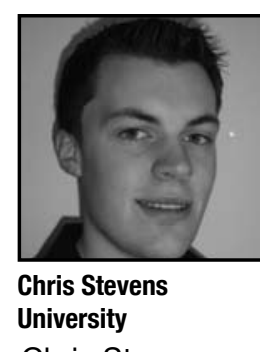

[ $\mathrm{n}$ this essay I will begin by briefly outlining Sartre's ontology (theory of being or existence) particularly in relation to the existence of others as presented in his Being and Nothingness. ${ }^{1}$ The focus will then move to his account of love, and Sartre's explanation of why we seek love as arising from his ontology. For Sartre the original mode of being-for-others is conflict, ${ }^{2}$ with any concrete relationships always destined to fail and cycle into some other self-defeating attitude towards the Other. I intend to analyze what he means by this, particularly with regard to love, which we would pre-philosophically consider a positive form of relationship that is not always destined to fail. Using Sartrean terminology, I will at positive relation with the Other, perhaps far from its optimistic ideal, but nevertheless providing some temporary relief from existential nausea.

For Sartre there are two irreducible ontological modes of being: the initself and the for-itself. The category of in-itself covers the material entities and bodies in the world that are non-conscious, and have absolute self-identity. The for-itself is the opposite, basically consciousness, lacking in any definite nature, able to adopt an attitude towards itself by being separated from itself by a nothingness, and thus is never identical to itself. The for-itself lacks self-identity as it can never encounter its own subjectivity as an object with a definite nature that can then independently identify itself with. As humans we combine both of these kinds of being; we are radically free consciousnesses combined with a materia body. It is the lack of the self-identity of the for-itself, a lack of anything to ground our being that makes us feel existential anguish; the feeling of incompleteness or pointlessness of human life. The fundamental project of the for-itself is to be identical to itself, to become an in-itself-for-itself and rid itself of anguish by becoming both subject and object. Sartre's analysis of love is intimately tied to this fundamental project of the for-

1. Jean-Paul Sartre, Being and Nothingness: An Essay on Phenomenological Ontology (London: Routledge 2lassics, 2003). itself with many of the distinctive phenomenological features of love being analyzed within the structure of his ontology.

Sartre, in his discussion of the quasi-ontological state of "being-for-others," observes that we cannot ordinarily treat others as mere objects in the world. we recognize them not as beings-in-themselves, but observe their body as realizing their own projects and freedom. We encounter the Other as a subject of sorts, but we cannot observe their being-for-themselves as this is a fundamentally reflexive mode of being. Further, we recognize that there are other free consciousnesses, that objectify and make judgements about us through the Look. It is our awareness of being looked at (the awareness of the presence of others) that Sartre identifies as the source of our self or personal identity as it is the realization of our being-for-others. Without the Other we are a pure transcendence, but when we become aware of the Other as a subject through the Look, ${ }^{3}$ we recognize that we can be an object for their consciousness; the Other can be "the foundation of my being-in-itself." Sartre talks about this grounding of personal identity in negative terms (the fall, shame etc.), but the Look is not hort of the Other. Rather, it is a fact that we cannot treat Others as pure subjects anymore than we can pure objects and must necessarily partly objectify them, and they us. This is what Sartre means when he talks of being-for-others being defined by conflict; we are always in a cycle of subject-object relation with the Other in which we each try to out-transcend the other.

Although Sartre talks of being-for-others in negative terms, there is a sense in which we desire the Other's existence and seek the objectification it provides. As noted above, as a foritself we cannot bring about our self-identity and this is fundamentally unsatisfying, but the existence of the Other does provide us in some way with a grounding for our own identity. The Other "causes there to be a being which is my being " 4 but we recognize that at the same time that this being does not strictly belong to us, we are responsible for the conception the Other has of us but not the foundation of it. Thus, Our being-for-others becomes "a natural Other has of us but not the foundation of it. Thus, Our being-for-others becomes "a natural
extension... of one's attempt to be oneself." ${ }^{5}$ We can try to use our relationships with othextension... of one's attempt to be oneself." ${ }^{5}$ We can try to use our relationships with oth-
ers to gain the self-identity that we lack and are unable to provide ourselves. The existence of the Other provides the foundation of our being, but we must recover this being from the Other for we recognize it is their conception not our own, and "thus my project of recovering myself is fundamentally a project of absorbing the Other."

In this project of self recovery we try to absorb the Other's freedom, which sees us as an object (and so retain our own freedom) while maintaining the Other's freedom as the ground for our being Sartre conceives of love as being a part of this "attempt to make the Other who is the source of my self-identity subservient to me."7 However, I must not "cease to assert the Other;" ${ }^{\prime \prime}$ that is, I must not deprive the Other of the quality of being something other than me as to do so would result in the disappearance of my being-for-others and any

3. Sartre, 385 .

4. Sartre, 386

5. Hazel E. Barnes, Sartre (London: Quartet Book Limited, 1973): 57.

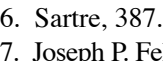

.

8. Sartre, 387. 


\section{A Critical Discussion of Sartre on Love}

concrete conception of my identity that I seek to attain. Furthermore, it is not the Other as object that I wish to absorb as it is precisely not the other-as-object that is capable of looking at me and providing my essence; I must absorb the Other as a freedom.

Sartre's analysis of love is of "eros" or romantic love. Sartre conceives that this form of love has as its ideal an absolute unity between lovers; a merging together of two free consciousnesses in which each grounds the other's being to form one consciousness. Through love we seek to attain the totality of being that is ontologically denied to the in-itself, through the use of the Other, whom we love. In love we seek to possess the freedom of the Other as the ground of my identity by becoming the same as that freedom. Thus we maintain "its character as a freedom," ${ }^{\prime \prime}$ and also find a ground for our own being-for-itself that that freedom has given us. It is important to note that this is something that both consciousnesses try to do through love; "the relations involved in being-for-others are reciprocal" 10 precisely because it is two free consciousnesses trying to encounter each other as such.

Common-sense should tell us that such an ideal is unattainable, and indeed Sartre's analysis reflects this; two consciousnesses can never encounter each other qua free consciousnesses. The unity with the Other as a ground of my being as the ultimate aim of love is an unattainable end, an impossible project. Such a unity would involve overcoming the individuation of our consciousnesses in a sharing of a body, but it would also erase the quality of viduatioss, which is the ground of our being. A unity is in fact unrealizable as we quality of dividuas, which is dividuated by our bity contains a contraction involve the dif are to succe dis chacter of othere tainable, it would destroy what was really aimed at by each of them. If two consciousnesse did become unified hen that unified conciousness would not provide its own grounds for However safre ris However, Satre recognizes that this ideal is not to be strictly identified with love, it is it motivation, and its end, its unique value, but it is not the only aspect or love. The ideal of love, and Satre andy at through the project of love so it is always in the bavground of our in-love in light of this.

The Other's freedom is the foundation of my being, and it is precisely this freedom that brings some conflict into the project of love. In love we wish to possess the freedom of the Other as a freedom; we want to be loved by a freedom and yet we cannot be satisfied by this. As Sartre notes "who would be satisfied with the words 'I love you because I have freely engaged myself to love you,' 12 the freedom of the Other is a poisoned chalice as it frustrate us by forcing us to consider the love as a mere contingency. If we conceive of the love a another contingency, then it is conceivable for the Other to revoke their love at any time and to deny our subjectivity through their Look (this would be Sartrean indifference or hate). Sartre thinks that this is the origin of the tendency of people in love to try to view their love

9. Sartre, 385

10. A. Stern, Sartre: His Philosophy and Existential Psychoanalysis (London: Vision Press Limited 1967): 151

11. Sartre, 388 . as necessary (It was meant to be," "We were made for each other," etc.). This attempt is a form of bad faith, a self-deception aimed at protecting oneself from the danger of existing "by means of the Other's freedom."13 If we manage to deceive ourselves into believing that our love is somehow necessary, then the lover can provide a non-contingent foundation for our being, and so we escape our existential anguish. Inasmuch as we can achieve this self-deception, Sartre thinks that this is the origin of the joy we experience of being in love as "we feel that our existence is justified."14 This is a welcome island of comfort in Sartre's pessimistic view of love, and helps to explain the phenomenological reality that, for much of the time, being-in-love is a deeply satisfying experience.

However, this desire for necessity provides a further problem, for the Other who we love However, this desire for necessity provides a further problem, for the Other who we love
seeks to make us the foundation of their subjective world also in loving us back. Sartre seeks to make us the foundation of their subjective world also in loving us back; Sartre object for our beloved (this would be Sartrean masochism). What we wish is that the loved will provide us with an objectivity for ourselves, to "serve as the foundation of my beed by objectifying [my] subjective world."16 If the loved through their freedom makes me the absolute end of their world, and I then identify my freedom with theirs, then I suceed in absolute my project the loved is no the affirm our identity is an to love. Love, as the desire to be loved, is love" 17 that even in the greatest love affirs there is some awareness of incompletens lover, 17 thateven in the greatest love aff and an unceasing desire for ever more.

Another psychological aspect of love that can be seen as ontologically revealing is the lover's desire for solitude. There is, in seeking a unity with the Other, also the problem of the existence of a third person or persons. If in love we are trying to attain a unity with another free consciousness, there is always the risk that another person will come along and objectify both of us through their own Look. The existence of a third person will reveal to us the object side of the loved, and so the loved is no longer the transcendence that founds our being, but a "transcendence transcended, not by me but by another." 18 This Sartre identifies as the true reason why lovers seek solitude, to prevent this obvious barrier to the possibility of a unity from being immediately present to them, and in doing so destroy the joy which being-in-love can temporarily provide.

We have seen that Sartre's ontology can explain why we seek love; the dissatisfaction with the lack of identity of the in-itself leads it to seek out another for assistance in its fundamental project of grounding its being. In love this project becomes the aim of a unity with the Other, a unity with the Otherness that is a ground of my being. The impossibility of a unity is clear, and it is plausibly the continued pretense that such a unity is possible that leads to conflict and ultimate breakdown of love. I have also discussed the way Sartre brings out the triple destructibility of love through some of its common psychological aspects. First, there

13. Sartre, 388.

14. Sartre, 393.

16. Barnes, 59 . 


\section{A Critical Discussion of Sartre on Love}

is the contingency of the love; we are always at risk of the beloved removing their love and objectifying us without recognising us as a subject. Second, if love is the desire to be loved then there is an infinite reflection between myself and the beloved where each is continually reminded of their own subjectivity. Lastly, there is the presence, or even the awareness possibility of the presence, of a third person who will objectify both partners and reveal once again the impossibility of a unity that love aims at. Sartre thus analyzes and explains key emotional aspects of love through his ontology, and concludes that ultimately love is a failure as it always results in my being "referred... to my own unjustifiable subjectivity -either by [the as it always results in my being "re unrealizable, and shows the impossibility of the realization of our fundamental project.

unrealizable, and shows the impossibity of the realization of our fundamental project. in its pretense that the ideves of unity is attainable, and it is merely part of a cycle which will in its pretense that the ideal of unity is attainable, and it is merely part of a cycle which will eventually slip into masochism, indifference, sadism or hate. It is human nature that we seek llly wish for it to be more than it can possibly be. Certainly if we think of love only as the idear the it must be a failure, it is obvious ideal, the it the is a clear conceptual contradiction in aiming at unity as to do so would erase the necessary qualally slip into mas ism or hate.

The question is whether we can accept the ultimate impossibility of the unity, yet still be satisfied that love as a project is a worthwhile endeavour. Working within Sartre's philosonial. Perhaps we can acept that a unity of love is only possible in the clichéd metaphors of nial. Perhaps we can accept that a unity of love is on possible in the clichéd metaphors of poets and songwriters; the recognition and respect of the lover as a subject and an (perhaps unspoken) agreenent from love. This may be far from the original aim and ideal of love, but perhaps we can accep that uniting self with self is a futile project, and leave the desire for a concrete identity from the Other behind us, to "merely" seek the joy that can be obtained through love despite the ontological contradictions of its ideal. Sartre himself seems to suggest such a thing is possible when he writes that in love "the Other experiences him as subjectivity and wishes to experience him only as such." ${ }^{21}$ It may be that this smaller conception of love will suffer by invidious comparison to the ideal that will remain in our thoughts, but it seems to me that this could form a sustainable project of love; I can find nothing in Sartre's thought to rule it out in principle.

So maybe we can accept that the for-itself s fundamental project is always in vain; but also recognize that in love it comes the closest it ever will to an experience of the subjectivity of the Other, and the closest we can come to overcoming the subject-object conflict seemingly inherent in all human relations. When we are in a state of being-in-love we recognize that there is a free consciousness who gives us a positive evaluation; we can be proud of ou being-for-others and they of theirs. We may wish for more from love; that it entirely grounds our being and provides us with a true identity, but this is too much to ask. Perhaps once we 